Bangladesh J. Bot. 49(3): 633-641, 2020 (September)

\title{
MORPHOLOGY, ANATOMY, PALYNOLOGY AND CONSERVATION STATUS OF ACHILLEA KETENOGLUI H. DUMAN
}

\author{
ONuR KoyunCU* \\ Department of Biology, Faculty of Science and Letters, \\ Eskisehir Osmangazi University, TR-26040 Eskisehir, Turkey \\ Keywords: Achillea ketenoglui, SEM studies, Conservation status, Biodiversity
}

\begin{abstract}
Achillea ketenoglui H. Duman is an endangered species in Turkey. Its morphological, anatomical and palynological features were studied. Microphotographs of the cross sections of stem and root of this species are provided along with the detailed anatomical features and their morphological description with the help of drawings. Distribution and ecology of A. ketenoglui were determined and IUCN risk category was revised. Microphotographs of scanning electron and light microscope was studied, evaluated and discussed for their taxonomic use.
\end{abstract}

\section{Introduction}

Asteraceae (Compositae) is one of the largest families of flowering plants occurring all over the world. According to the angiospermic phylogeny Asteraceae is placed in Asterideae/Asterales. Its members are distributed particularly in semiarid region of the tropics and subtropics with about 1600 - 1700 genera and 24000 species around the world (APG 1998, APG II 2003, APG III 2009, APG IV 2016).

The Achillea L. one of the genera of Asteraceae belongs to tribe Anthemideae. It is represented by 115 taxa throughout the world and by 58 taxa in Turkey. Because of its high endemism ratio (53\%) Achillea $\mathrm{L}$. is considered as an important genus among the Asteraceae genera available in Turkey Arabacı 2012, Aytaç et al. 2016). Previously Achillea L. was revised by Huber-Morath (1975) in the flora of Turkey.

Thereafter Duman (2000) added new species in second supplement of the Flora of Turkey. The new species were collected and described by Aytaç et al. (1990) from marly steppes between Polatli and Sivrihisar (Duman 2000). Studies were carried out on Achillea taxa by both local and foreign workers on different aspects, mostly on chemical components and their importance for anticancer, antimicrobial etc. (Tabanca et al. 2016, Haliloğlu et al. 2017, Demirci et al. 2018, Özek et al. 2018). Studies on morphology, anatomy and palynology of A. ketenoglui H. Duman are still limited (Arabacı 2006, Akyalçin et al. 2009, 2011, 2014, Grytsyk 2016, Dauti et al. 2017). In the present study the detailed morphological, anatomical and palynological features of the Achillea ketenoglui $\mathrm{H}$. Duman were investigated for the first time.

\section{Materials and Methods}

The specimens of Achillea ketenoglui were collected from Günyüzü, between GünyüzüYazır, (Eskişehir-Turkey) gypsicolous area, N 39 25' 40.1" - E 31 49' 29.8", 810 m., 29.06.2018, OUFE: 18242 (Fig. 1). In order to carry out a systematic study of the plant material, herbarium samples were prepared and kept as voucher specimens at the Eskişehir Osmangazi University Herbarium (OUFE). For the anatomical studies, fresh plant specimens collected from the natural habitat were fixed in $70 \%$ alcohol. Transverse sections of the stem and root were made by hand with the help of a scalpel.

\footnotetext{
*Author for correspondence: <omurkoyuncu@gmail.com>.
} 
The thickness of each section was identified by Leica EZ-40 stereomicroscope from the herbarium samples stored in OUFE. To identify the range of variation in descriptive morphologic characters, 25 plant specimens from different locations were investigated. A number of relevant literatures were consulted for naming and their comparison made Davis et al. (1965, 1988), Esau (1967), Fahn (1967), Yentür (1995), Güner et al. (2000).

Pollen samples obtained from the herbarium materials of A. ketenoglui were stored in OUFE. For palynological investigations, pollen grains of 10-15 from each plant specimen collected from different localities were used. Light microscopy and SEM were used for investigation of their morphology. The terminologies used by Faegri and Iversen (1975) were followed to name the exine layers. For the purpose of investigations by light microscope, pollen grains of A. ketenoglui were prepared following Wodehouse (1935) and Erdtman (1969) techniques. For identifications and counting of pollen grains simply 10 and 40x objectives were used. Detailed investigations on their identifications were made by 100x plan oil-immersion objective. Thickness of exine and intine of seeds of the taxa was measured following Wodehouse (1935) and Erdtman (1969). Terminologies for pollen morphology were used as par Wodehouse (1935), Kuprianova (1967), Erdtman (1969) and Faegri and Iversen (1975).

\section{Results and Discussion}

To identify the anatomical features of Achillea ketenoglui the transverse sections of its stem and root were investigated. In stem, the epidermis was covered by simple multicellular hairs. Epidermal cells were surrounded by a thick and slightly undulated cuticle. Cortex was made up of 4-12-layers of parenchymatous cells. One-5-layered collenchymatous tissue located below the epidermis. Cortical cells were found to be ovoid in median layer and squash towards to the phloem. There was a thick sclerenchymatous sheath on the phloem tissue which occupie a wide region. Cambium was not distinguishable and the pith region was composed of large and parencymatic cells. Starch grains were observed in some cells of the pith (Fig. 2).

There was a primarly periderm layer on the outer surface of the root. Its cells are crushed, broken up and sometimes worn out parenchymatous cortex is present under the-peridermal layer/s of cells. The breadth of the cells was bigger than the length. These cells have regularly 2-4 layers. Endoderm was located at the end of cortical layer. Phloem occupied a narrow area between scleranchyma bundles and xylem. Cambium cells were distinguishable. In contrast to the older ones, any parenchymatous pith region was not found in young root sections (Fig. 3).

According to data obtained from morphological studies, detailed description of A. ketenoglui is given here. Perennial herb c. 8 - 24 high, not branched, angled, densely lanate-tomentose, bearing many underdeveloped shoots of to $2.7 \mathrm{~cm}$ long. Leaves linear-oblong, $10-20(-20.7) \times 1$ - $2.2 \mathrm{~mm}$, sessile, pinnatisect, divided into dense imbricate segments $(0.3-0.6 \times 0.5-1 \mathrm{~mm})$, young segments are not divided, medians are 3 - 5 partitate or 3 - 5 lobed, all lobes are same in shape, orbicular, 0.3 - $0.5(-0.9) \mathrm{mm}$ long and margine cartilaginous, denticulate, lanate-tomentose (Fig. 4). Capitula $3-5(-8)$. Corymbs $1-5 \mathrm{~cm}$ wide: peduncles $0.5-1.5 \mathrm{~cm}$ long. Involucre broadly ovoid to hemisphaerical. $3-5 \times 3-4 \mathrm{~mm}$, rounded at base (Fig. 5). Phyllaries $4(-5)$ serried, with scarious brownish or hyaline margins, tomentose; outher phyllaries are ovate, lanceolate, $2 \times 0.5$ - $0.8 \mathrm{~mm}$, acute; inner ones are ovate, $3.3-4.2 \times 1.2-1.7 \mathrm{~mm}$, obtuse. Palea 3 $3.8 \times 0.5-1 \mathrm{~mm}$, lanceolate, margin of upper parts and apex hyaline, inner side of palea glabrous, outher side pilose to villous towards the apex. Ligules $5-8$, white, $3.8-5.5 \times 3.5-4.5 \mathrm{~mm}$, lamina obtrapeziform, $2-4 \times 2.7-4.9 \mathrm{~mm}$, tri-lobed, disc flowers $30-40$, achenes are oblong to lanceolate, $1.3-2.8 \times 1.2-1.5 \mathrm{~mm}$ (Figs 6-7, Table 1). 

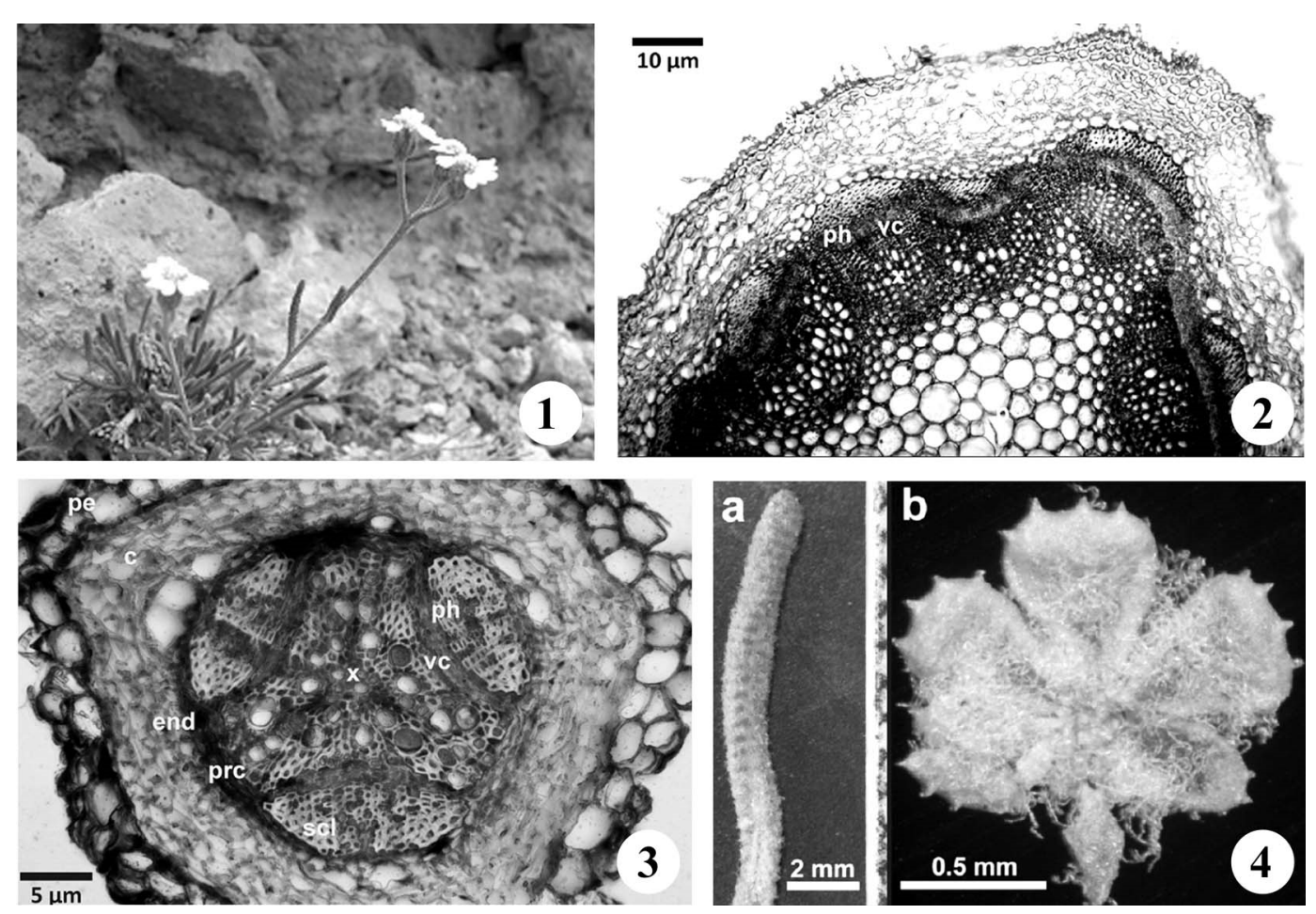

Figs 1-4: 1. The general appearance of A. ketenoglui in nature. 2. Cross section of the stem of A. ketenoglui (ep: Epidermis, c: Cortex, scl: Sclerenchyma, ph: Phloem, vc: Vascular cambium, x: Xylem, p: Pith) (10 x 10). 3. Cross section of the root of A. ketenoglui (pe: Peridermis, c: Cortex, end: Endodermis, prc: Pericycle, ph: Phloem, x: Xylem, vc: Vascular cambium) (20x10). 4. Leaves of A. ketenoglui (a: General view of the leaves; $\mathrm{b}$ : Detailed view of a leaf).

To date the descriptive features of the Achillea ketenoglui H. Duman are available in only two reports. First one of these reorts was published in the second supplement of the Flora of Turkey and in the East Aegean Islands. With the help of detailed description A. ketenoglui H. Duman is now introduced to the scietific world through the present study. The detailed description is given in it. Somehow or other, information about most of the important taxonomic characters such as palea and achene are not given here. For example, morphological characteristics of achene in Asteraceae is noted to have especial or high importance for the purpose of classification. Besides, other morphological characters have not also been given in detail in this study too. As such the lapse may create or cause problems revealing the distinction in clear terms between Achillea ketenoglui H. Duman and its related taxa. Another important work in which morphological characters of A. ketenoglui were discussed is "The revision of Achillea L. (Asteraceae) genus grown in Turkey", which was completed by Arabaci in 2006 as a part of his $\mathrm{PhD}$ thesis. In this study, some of the missing data) of some taxonomic characters, namely achene and palea are given. The results obtained from the morphological evaluation carried out here are largely in line with the morphological data to those of Arabacı (2006). However, some small deviations have been determined especially in terms of variational values of numerical measurements. In addition, supporting the relevant morphological characters with photographs of living plant specimens eliminates the lack of visual data on these characters. 

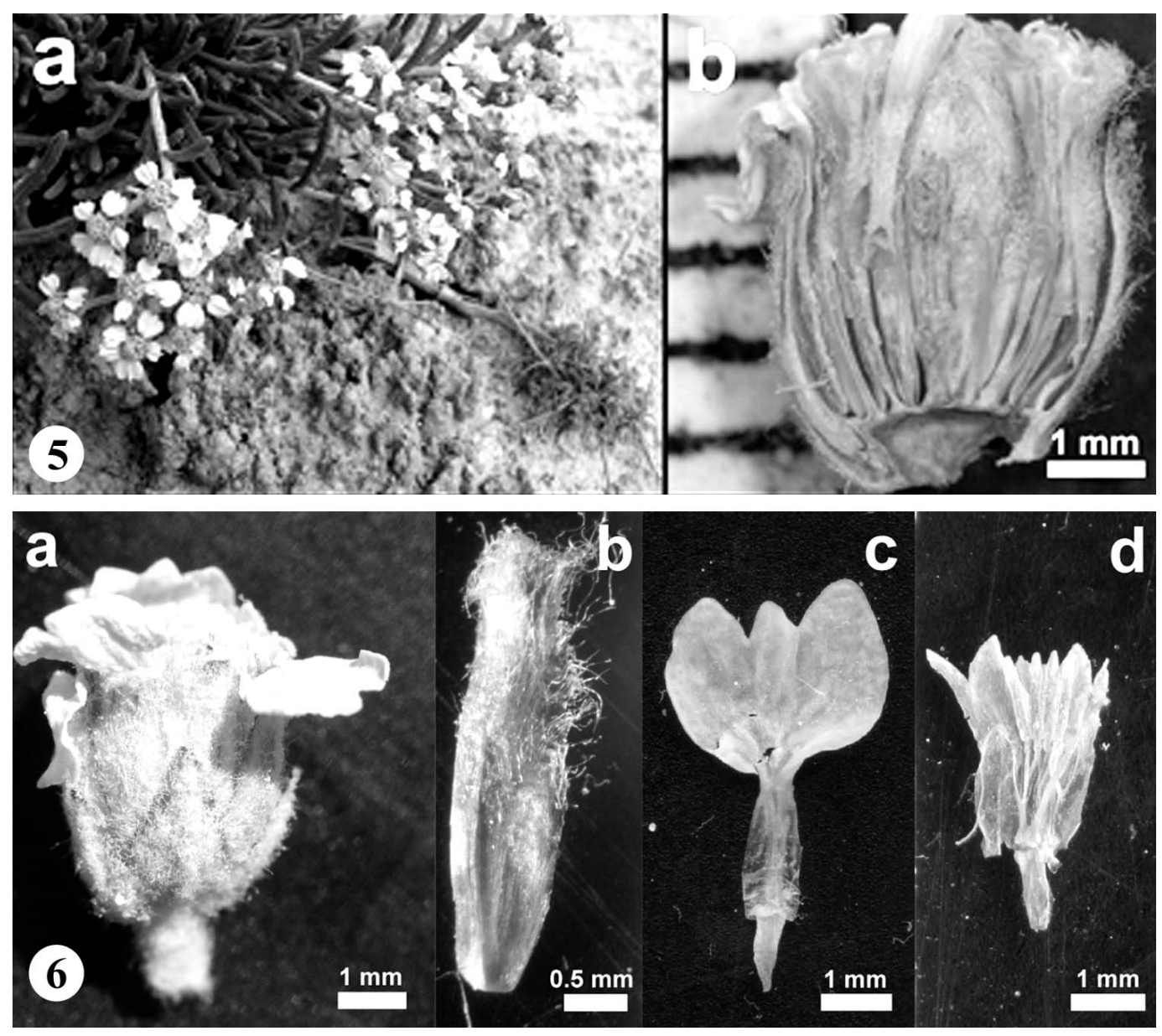

Figs 5-6: 5. Capitula of A. ketenoglui (a: General view of the capitulas at corymb; b: Longitudinal section of a capitula). 6. Phyllaries and flowers of A. ketenoglui (a: Phyllaries; b: Palea, c: Ligulate flower, d: Tubulate flower).

A. ketenoglui H. Duman, endemic to Turkey, and distributed in Central Anatolia is located within the borders of the Irano-Turanian phytogeographic region. It is located at the B3 and B4 squares according to Davis' square system. A. ketenoglui were found in gypsum and marl areas in the borders of Eskişehir (Bozan, Sivrihisar and Günyüzü), Ankara (Polatlı and Beypazarı) and Kırıkkale (Kesikköprü) provinces.

A. ketenoglui on the gypsum and marl areas of marble bedrocks with high level of $\mathrm{CaCO}_{3}$. In natural habitats, it was found in association of other calcicolous taxa, such as, Alyssum niveum Dudley, Asperula nitida Smith, Aubrieta canescens Boissier, Aethionema subulatum Boissier, Astragalus oxytropifolius Boissier, Cota tinctoria J. Gay ex Gussone, Cephalaria aytachii Göktürk \& Sümbül, Hedysarum cappadocicum Boiss., Scabiosa hololeuca Bornm., Achillea gypsicola Hub.-Mor., Matthiola anchonifolia Hub.-Mor., Linum hirsutum L. and Gypsophila perfoliata $\mathrm{L}$.

According to field surveys made by the authors, natural populations of A. ketenoglui $\mathrm{H}$. Duman were also found at different localities from of Eskişehir, Ankara and Kırıkkale provinces. 
The area of occupancy (AOO) of the natural populations were changed from 1 to $10 \mathrm{~km}^{2}$ and so the size of its population is found to be between 200 to 900 individuals. On the basis of gathered data and on the basis of IUCN Red List Categories (IUCN 2017), A. ketenoglui H. Duman was proposed as "Vulnerable [VU: B1ab (i)]" and its no change at the IUCN category is proposed.

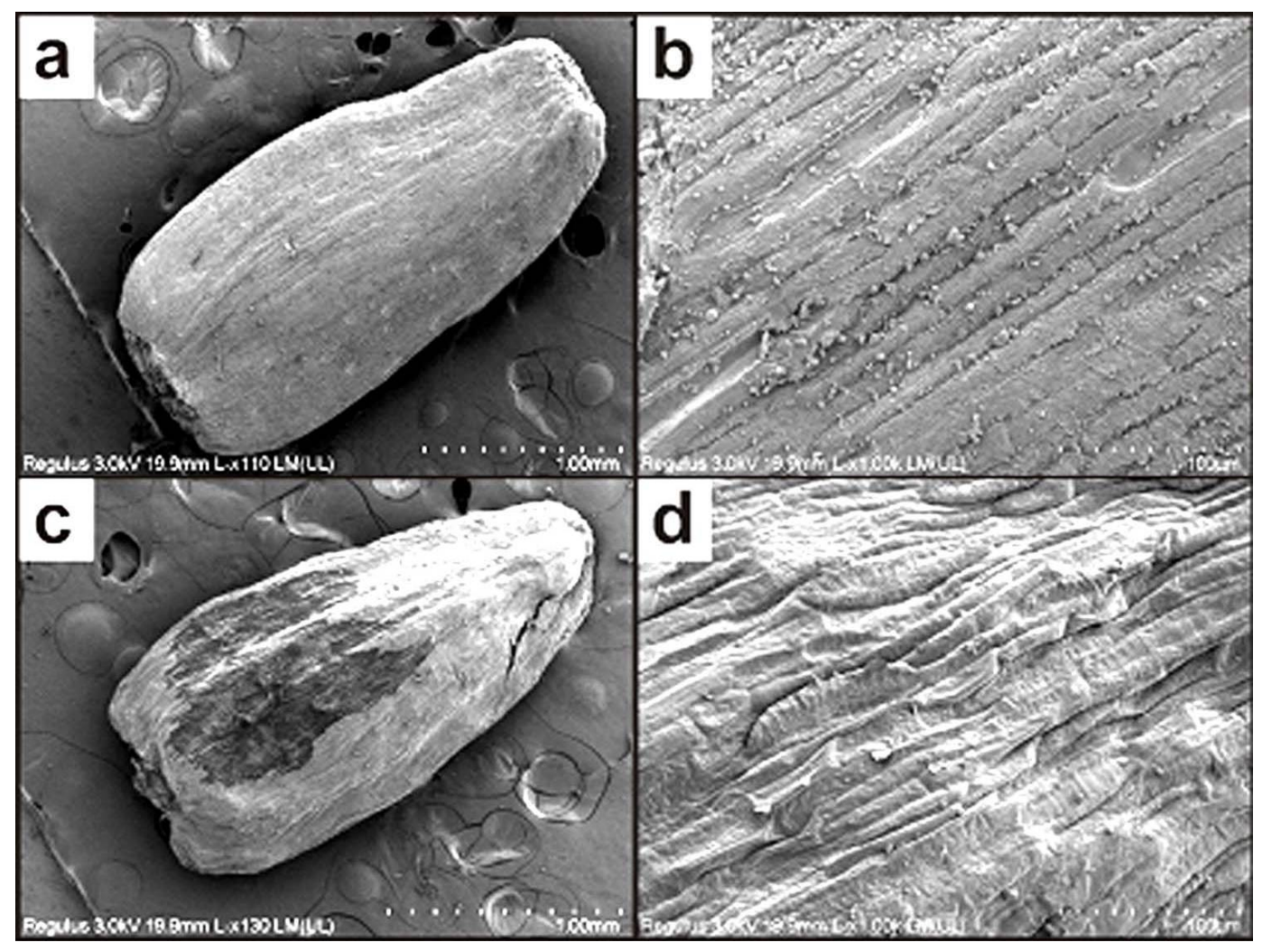

Fig. 7. Achene of A. ketenoglui in SEM (a: Ventral view of achene, b: Ventral surface of achene and c: Dorsal view of achene, d: Dorsal surface of achene).

The results of the study of LM and SEM revealed that in the echinate tricolporate and exine scabrate of A. ketenoglui H. Duman, P/E ratio ranged from 1.07 - 1.12 (Fig. 8, Table 2). Mean values of non-acetolysed pollen grains were $27 \mu \mathrm{m}(\mathrm{P})$ and $25.30 \mu \mathrm{m}(\mathrm{E})$ as against $30.20 \mu \mathrm{m}(\mathrm{P})$ and $26.90 \mu \mathrm{m}$ in acetolysed pollen grains (E) (Table 2).

The essential criteria used for the determination of the phylogenetic relationship of the characteristics of the aperture and function of this species have been reported by Kuprinova (1967), Cronquist (1968), Walker (1974a-b) and Takhtajan (1980). In the present data analysis of these taxa, authors observed that genetic distinctions encompassed differences in the measurements, raising objections to the possession of a morphological characteristic on to the pollen structure of these species. 
Table 1. Comparison of identified morphological characters of A. ketenoglui with type description of Güner et al. 2000 and Arabaci 2006).

\begin{tabular}{|c|c|c|c|}
\hline Characters & $\begin{array}{l}\text { A.ketenoglui } \\
\text { (this study) }\end{array}$ & $\begin{array}{l}\text { A. ketenoglui } \\
\text { (Arabac1 2006) }\end{array}$ & $\begin{array}{l}\text { Type description } \\
\text { (Güner et al. 2000) }\end{array}$ \\
\hline Stem & $\begin{array}{l}\text { Perennial herb c. } 8-24 \text { high, } \\
\text { unbranched, angled, densely } \\
\text { lanate-tomentose, bearing many } \\
\text { sterile shoots to } 2.7 \mathrm{~cm} \text { long }\end{array}$ & $\begin{array}{l}\text { Perennial herb c. } 10-20 \text { high, } \\
\text { unbranched, angled, densely } \\
\text { lanate-tomentose, bearing } \\
\text { many sterile shoots }\end{array}$ & $\begin{array}{l}\text { Perennial herb c. } 10 \mathrm{~cm} \\
\text { high, cylindrical, obtuse- } \\
\text { angled, densely lanate } \\
\text { tomentose, sterile shoots } \\
\text { well-developed to } 3 \mathrm{~cm} \\
\text { long }\end{array}$ \\
\hline Leaves & $\begin{array}{l}\text { Leaves linear-oblong, } 10-20 \\
(-20.7) \times 1-2.2 \mathrm{~mm} \text {, sessile, } \\
\text { pinnatisect, divided into dense } \\
\text { imbricate segments; segments } \\
0.3-0.6 \times 0.5-1 \mathrm{~mm} \text {, young } \\
\text { segments not divided, medians } \\
\text { are } 3-5 \text { partitate or } 3-5 \text { lobed, all } \\
\text { lobes are same shaped, orbicular, } \\
0.3-0.5(-0.9) \text { mm long and lenght, } \\
\text { margine cartilaginous, } \\
\text { denticulate, lanate-tomentose }\end{array}$ & $\begin{array}{l}\text { Homomorphic, linear, } 10-20 \\
(-2.30) \times 1-2 \mathrm{~mm} \text {, sessile, } \\
\text { sometimes crooked, } \\
\text { pinnatisect, divided into dense } \\
\text { imbricate segments; segments } \\
0.3-0.5 \times 0.7-1 \mathrm{~mm} \text {, not } \\
\text { divided, tri-partitate or tri- } \\
\text { lobed, all lobes are same } \\
\text { shaped, orbicular, } 0.3-0.5 \mathrm{~mm} \\
\text { long and lenght, margine } \\
\text { cartilaginous, small tooted, } \\
\text { lanate-tomentose }\end{array}$ & $\begin{array}{l}\text { Median leaves } 10-20 \times 1-2 \\
\text { mm, lanate, tomentose, } \\
\text { linear oblong, pinnatisect; } \\
\text { segments densely } \\
\text { imbricate, } 3-5 \text { lobed or 3-5 } \\
\text { partite, rarely undivided; } \\
\text { lobes orbicular, } \\
\text { denticulate, } 0.5-1 \mathrm{~mm} \text { long }\end{array}$ \\
\hline Capitula & $3-5(-8)$ & $3-5(-8)$ & $3-5(-8)$ \\
\hline Corymbs & $1-5 \mathrm{~cm}$ wide & $1-5 \mathrm{~cm}$ wide & $1-5 \mathrm{~cm}$ wide \\
\hline Peduncles & $0.5-1.8 \mathrm{~cm}$ & $0.5-2 \mathrm{~cm}$ & $0.5-1.5 \mathrm{~cm}$ \\
\hline Involucre & $\begin{array}{l}\text { Broadly ovoid to hemisphaerical, } \\
3-5 \times 3-4 \mathrm{~mm} \text {, rounded at base }\end{array}$ & $\begin{array}{l}\text { Broadly ovoid to } \\
\text { hemisphaerical, } 3-5 \times 3-4 \\
\text { mm, rounded at base }\end{array}$ & $\begin{array}{l}\text { Broadly ovoid to } \\
\text { hemisphaerical, } 3-5 \times 3-4 \\
\text { mm, rounded at base }\end{array}$ \\
\hline Phyllaries & $\begin{array}{l}4(-5) \text { serried, with scarious } \\
\text { brownish or hyaline margins, } \\
\text { tomentose; outher phyllaries are } \\
\text { lanceolate, } 2 \times 0.5-0.8 \mathrm{~mm} \text {, } \\
\text { acute; inner ones are ovate, } 3.3 \text { - } \\
4.2 \times 1.2-1.7 \mathrm{~mm} \text {, obtuse }\end{array}$ & $\begin{array}{l}4 \text { serried, with scarious } \\
\text { brownish or hyaline margins, } \\
\text { tomentose; outher phyllaries } \\
\text { are lanceolate, } 2 \times 0.5 \mathrm{~mm} \text {, } \\
\text { acute; inner ones are ovate, } \\
3.5-4 \times 1.5 \mathrm{~mm} \text {, obtuse }\end{array}$ & $\begin{array}{l}\text { Ovate-lanceolate, carinate, } \\
\text { densely tomentose, obtuse, } \\
\text { brownish, with norrow, } \\
\text { scarious margins }\end{array}$ \\
\hline Palea & $\begin{array}{l}\text { Palea } 3-3.8 \times 0.5-1 \mathrm{~mm} \text {, } \\
\text { lanceolate, margin of upper parts } \\
\text { and apex hyaline, inner side of } \\
\text { palea glabrous, outher side pilose } \\
\text { to villous towards the apex }\end{array}$ & $\begin{array}{l}\text { Palea lanceolate, } 3-3.5 \times 0.5-1 \\
\text { mm, acute, apex hyaline, } \\
\text { pilose }\end{array}$ & - \\
\hline Ligules & $\begin{array}{l}5-8, \text { white, } 3.8-5.5 \times 3.5-4.5 \mathrm{~mm} \text {, } \\
\text { lamina obtrapeziform, } 2-4 \times 2.7- \\
4.9 \mathrm{~mm} \text {, tri-lobed }\end{array}$ & $\begin{array}{l}\text { 5-7, white, } 4-5 \times 3.5-4.5 \mathrm{~mm} \text {, } \\
\text { lamina obtrapeziform, } 2-4 \times \\
3.5-4.5 \mathrm{~mm} \text {, tri-lobed }\end{array}$ & 5-7, white, 2-2.5 $\mathrm{mm}$ long \\
\hline $\begin{array}{l}\text { Disc } \\
\text { flowers }\end{array}$ & $30-40$ & $30-40$ & $30-40$ \\
\hline Achene & $\begin{array}{l}\text { Obovate to oblong, } 1.1-2.3 \times 0.7- \\
1.5 \mathrm{~mm}\end{array}$ & $\begin{array}{l}\text { Are broadly obovate to } \\
\text { oblong, } 1-1.5 \times 0.6-0.9 \mathrm{~mm} \text {, } \\
\text { lineolate, grey-white colored }\end{array}$ & - \\
\hline Flowering & $5-6$ & 5 & 5 \\
\hline
\end{tabular}




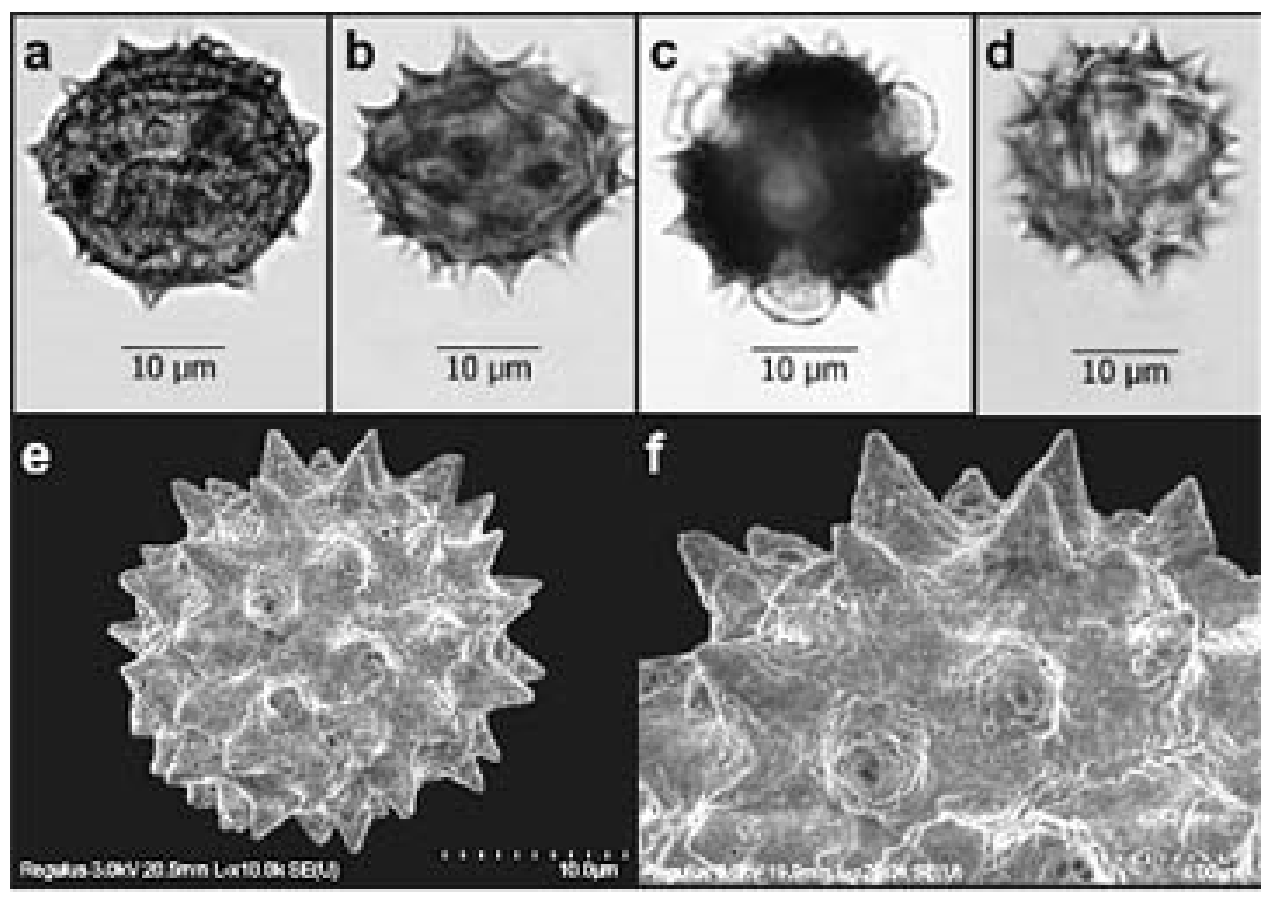

Fig. 8. Pollen grains of A. ketenoglui (a: Equatorial view of non-acetolised pollen grain; b: Equatorial view of acetolised pollen grain, c: Polar view of non-acetolised pollen grain, d: Polar view of acetolised pollen grain e: General view of pollen grain in SEM and f: Exine ornamentation of pollen grain in SEM).

Table 2. Pollen morphometrical parameters of A. ketenoglui $(\mu \mathrm{m})$; (P: Polar axis; E: Equatorial axis; M: Mean; S: Standard deviations).

\begin{tabular}{|c|c|c|c|c|c|c|c|c|c|c|c|c|c|}
\hline & \multicolumn{2}{|l|}{$\mathrm{P}$} & \multicolumn{2}{|l|}{ E } & \multicolumn{2}{|l|}{$\mathrm{P} / \mathrm{E}$} & \multirow{2}{*}{$\begin{array}{l}\text { Aperture } \\
\text { number }\end{array}$} & \multirow{2}{*}{$\begin{array}{l}\text { Ornamen- } \\
\text { tation }\end{array}$} & \multirow{2}{*}{$\begin{array}{l}\text { Pollen } \\
\text { shape }\end{array}$} & \multicolumn{2}{|c|}{ Exine } & \multicolumn{2}{|c|}{ Intine } \\
\hline & M & S & M & $S$ & M & $S$ & & & & M & $S$ & M & $\mathrm{S}$ \\
\hline $\begin{array}{l}\text { Non- } \\
\text { acetolysed } \\
\text { (this study) }\end{array}$ & 27 & \pm 0.4 & 25.3 & \pm 0.4 & 1.07 & \pm 0.24 & 3 & Echinate & $\begin{array}{l}\text { Prolate- } \\
\text { spheroidal }\end{array}$ & 4.2 & \pm 0.2 & 1.1 & \pm 0.4 \\
\hline $\begin{array}{l}\text { Acetolysed } \\
\text { (this study) }\end{array}$ & 30.2 & \pm 0.3 & 26.9 & \pm 0.3 & 1.12 & \pm 0.17 & 3 & Echinate & $\begin{array}{l}\text { Prolate- } \\
\text { spheroidal }\end{array}$ & 4.6 & \pm 0.4 & - & - \\
\hline
\end{tabular}

\section{Acknowledgements}

Author are thankful to Dr. Okan SEZER for his help in improving the ms. This study was supported by Eskişehir Osmangazi University Scientific Research Projects Coordinatorship (Project number: 2018-2204, project title: Some Flora, Fauna and Habitat/Ecosystem Monitoring of Eskişehir Province) is also gratefully acknowledged.

\section{References}

Akyalçın H, Arabacı T and Yıldız B 2014. Pollen morphology of some Achillea L. sect. Babounya (DC.) O. Hoffm. (Asteraceae) species from Turkey. Acta Bot. Gallica. 161(2): 129-149. 
Akyalçın H, Arabacı T and Yıldız B 2011. Pollen Morphology of Six Achillea L. Sect. Achillea (Asteraceae) Species in Turkey. Turk. J. Bot. 35: 183-201.

Akyalçın H, Arabacı T and Yıldız B 2009.Türkiye'de Yetişen Achillea L. (Asteraceae) Taksonlarının Polen Morfolojisi. Tubitak Project Database. 104T291. (In Turkish). Available from: https://rdizin.gov.tr/ publication/show/pdf/project/TVRBNE5EQXc=

APG 1998. An ordinal classification for the families of flowering plants. Ann. Missouri Bot. Gard. 85: 531553.

APG II 2003. An update of the Angiosperm Phylogeny Group classification for the orders and families of flowering plants: APG II. Bot. J. Linn. Soc. 141: 399-436.

APG III 2009. An update of the Angiosperm Phylogeny Group classification for the orders and families of flowering plants: APG III. Bot. J. Linn. Soc. 161: 105-121.

APG IV 2016. An update of the Angiosperm Phylogeny Group classification for the orders and families of flowering plants: APG IV. Bot. J. Linn. Soc. 181: 1-20.

Arabacı T 2006. Türkiye'de Yetişen Achillea L. (Asteraceae) Cinsinin Revizyonu. PhD Thesis, İnönü University, Institute of Science and Technology, Malatya, Turkey. (In Turkish).

Arabacı T 2012. Achillea L. In: Türkiye Bitkileri Listesi (Damarlı Bitkiler), Güner A, Aslan S, Ekim T, Vural M and Babaç MT (Eds), pp. 108-112. Nezahat Gökyiğit Botanik Bahçesi ve Flora Araştırmaları Derneği, İstanbul. (In Turkish).

Aytaç Z, Duman H and Ekici M 2016. Two new Achillea L. (Asteraceae) species from Turkey. Turk. J. Bot. 40: 373-379.

Cronquist A 1968. The Evolution And Classification Of The Flowering Plants. Thomas Nelson Ltd. Edinburgh, London.

Dauti A, Kapidani G, Pupuleku B, Kallajxhiu N, Jançe A and Turku S 2017. Palynomorphological Data of Some Species of the Genus Achillea. Acad. J. Interdiscip. Stud. 5(3 S1): 74.

Davis PH (ed.) 1965-1985. Flora of Turkey and the East Aegean Islands. vol. 1-9. Edinburgh University Press, Edinburgh.

Davis PH, Tan K and Mill RR 1988. Flora of Turkey and the East Aegean Islands. vol. 10 (Suppl. I). Edinburgh University Press, Edinburgh.

Duman H 2000. Achillea L. In: Güner A, Özhatay N, Ekim T, Başer KHC, editors. Flora of Turkey and the East Aegean Islands (Suppl. 2), Vol. 11. 1st ed. Edinburgh, UK: Edinburgh University Press, pp. 158159

Demirci B, Başer KHC, Aytaç Z, Khan SI, Jacob MR and Tabanca N 2018. Comparative Study of Three Achillea Essential Oils from Eastern Part of Turkey and their Biological Activities. Rec. Nat. Prod. 12(2): 195-200.

Erdtman G 1969. Handbook of palynology, morphology, taxonomy, ecology. An introduction to the study of pollen grains and spores. Hafner Pub, New York.

Esau K 1967. Plant Anatomy. 2d Ed. J. Wiley.

Faegri K and Iversen J 1975. Textbook of pollen analysis. 3rd edn by Knut Faegri. Scandinavian University Books, Copenhagen, 294 pp.

Fahn A 1967. Plant anatomy. Pergamon Press, New York.

Grytsyk AR, Neiko OV and Melnyk MV 2016. Morphological-anatomical study of Achillea L. species in western region of Ukraine. Pharma Innovation 5(1B): 71.

Güner A, Özhatay N, Ekim T and Başer KHC 2000. Flora of Turkey and the East Aegean Islands. vol. 11 (Suppl. II). Edinburgh University Press, Edinburgh.

Haliloğlu Y, Özek T, Tekin M, Göğer F, Başer KHC and Özek G 2017. Phytochemicals, antioxidant, and antityrosinase activities of Achillea sivasica Çelik and Akpulat. Int. J. Food. Prop. 20(1): 693-706.

Huber-Morath A 1975. Achillea L. In: Davis PH, editor. Flora of Turkey and the East Aegean Islands, Vol. 5. $1^{\text {st }}$ ed. Edinburgh, UK: Edinburgh University Press, pp. 224-252. 
IUCN 2017. Guidelines for Using the IUCN Red List Categories and Criteria. Version 13, March 2017. Available from: http://cmsdocs.s3.amazonaws.com/ RedListGuidelines.pdf

Kuprianova A 1967. Apertures of pollen grains and their evolution in angiosperms. Rev. Palaeobot. Palyno. 3: $73-80$.

Özek G, Tekin M, Haliloğlu Y, Başer KHC and Özek T 2018. Chemical Compositions of Achillea sivasica: Different Plant Part Volatiles, Enantiomers and Fatty Acids. Rec. Nat. Prod. 12(2): 142.

Tabanca N, Demirci B, Aytaç Z and Başer KHC 2016. Chemical composition of Achillea schischkinii Sosn., an endemic species from Turkey. NVEO. 3(4): 24-28.

Takhtajan AL 1980. Outline of the classification of flowering plants (Magnoliophyta). Bot. Rev. 46.

Walker JW 1974a. Evolution of exine structure in the pollen of primitive Angiosperms. Am. J. Bot. 61: 891-902.

Walker JW 1974b. Aperture evolution in the pollen of primitive Angiosperms. Am. J. Bot. 61: 1112-1137.

Wodehouse RP 1935. Pollen grains. Mc Grew Hill, New York.

Yentür S 1995. Bitki Anatomisi. İstanbul Üniversitesi, Fen Fakültesi, İstanbul. (In Turkish).

(Manuscript received on 23 July, 2019; revised on 24 December, 2019) 